\title{
Free Sunday-Loss, Deprivation or Welfare
}

\author{
Elza Jurun \\ Faculty of Economics \\ Business and Tourism \\ University of Split \\ Phone: +38521430648 \\ Email: elza@efst.hr \\ Croatia \\ Nada Ratković \\ Faculty of Economics \\ Business and Tourism \\ University of Split \\ Phone: ++ 38521824171 \\ Email: nada.ratkovic@efst.hr \\ Croatia \\ Bože Vuleta \\ Franciscan Institute for Culture of Peace \\ Phone: ++385989197 132 \\ Email: fbvuleta@gmail.com \\ Croatia
}

\section{ABSTRACT}

This paper presents the part of results obtained by a comprehensive statistical analysis of public opinion in the issue of work-free Sunday, based on a survey undertaken in the Republic of Croatia in October 2017. The research has been made aiming at providing the answer to the crucial question of whether free Sunday can be considered only as of the economic issue or concerns deeply almost all the spheres of life in general. Moreover, the authors want to show and promote free Sunday as socio-economic phenomena which become a political and ideological issue as a fundamental human right and true notion of human freedom and welfare. Besides, as a member of the European Sunday Alliance, Croatia is the first EU member state which promotes free Sunday as one of the measures of active demographic policy. Along with the results of classical statistical processing of public opinion research, the methodology of this research has also involved the hypothesis testing about differences in the proportions as well as post-stratification of the two-step stratified random sample based on gender, age, size of residence, regions and education level. Even more, than two-thirds of respondents consider important or exceptionally important notworking on Sundays and support the maximum limit of that work.

Keywords: free Sunday; European legislation; turnover in fiscalization in Retail trade; active demographic policy; public opinion survey; statistical analysis; two-step stratification

\section{Introduction}

This work has emerged as a practical need to launch further research based on the conclusions of the conference entitled „Free Sunday and Dignified Working Time in Europe: What is the Way Forward?" The conference was organized by the European Sunday Alliance at the European Parliament in Brussels, February 2019. Why the phenomenon of the non-working Sunday as a historical legacy is so important for living in modern Europe?

It is like the man to be free; he is called to be a brother equal in dignity with all of his brothers and sisters in the human species. These are the leitmotifs of the French
Revolution that it has taken from the Gospel.(Črpić, Džolan,2014) These are very powerful ideas, the foundations of the development of our civilization. At the general level, many, if not all, will agree with these great ideas. However, when we ask how to be free today, a series of sub-questions open up: Where are the modern forms of enslavement? Who are the new slaveholders of our bodies and souls? Whose dignity we should protect, why and how? In some European countries, especially in Croatia, that means looking at the situation of women and men employed in retail stores. The situation in which these people are is closer to the state of slavery than the state of freedom. In Croatia people who 


\section{International Journal of Business and Applied Social Science (IJBASS)}

E-ISSN: 2469-6501

VOL: 6, ISSUE: 4

April/2020

DOI: 10.33642/fjbass.v6n4p2

work in retail stores are forced to work overtime, to work on holidays and Sundays. Formally, everything looks legitimate but in reality, they are not paid for overtime work nor their work on Sundays. If so, they are shamelessly underpaid.

Not only does the situation have negative consequences on their families, but also on society as a whole. The damages are even worse since most of these employees are women. Too much exploited and more absent than present in their families, women cannot effectively raise and educate their children. In the long run, this most likely generates and spreads violent behavior among children and young adolescents and consequently in society as a whole. That is why it concerns all the citizens and common freedom.

Moreover, what is happening to the employees in the retail trade today could soon happen to everyone else. The big capital knows no borders. In the Croatian language, the day devoted to the man and God, the day of the family, the day that enables and promotes freedom has a very indicative name ,ne-djelati“", which means ,non-working““.

With the theme of non-working Sunday, it should be borne in mind that premature workers are more likely to get sick, especially from chronic illnesses.

As a rule, burly capital destroys all public expenditures, and this also applies to the reduction of the level of public health care. Consequently, an increase in social problems can be expected as well as the delinquent behavior of the impoverished. A particularly vulnerable group is formed by chronically-diseased middle-aged employees who at their firms become the technological surplus. They fall at the expense of the state and the state should be protected in that sense. To put it better, the state should first protect its citizens because that is its primary task.

It is particularly necessary to look at the social significance of the Sunday and its impact on family welfare. Joining European Sunday Alliance Croatia has enriched the scope of arguments for work-free Sunday by extending its relevance for demographic state and trends. Croatian Sunday Alliance has been first to propose free Sunday as one of the main measures of active demographic policy.

The results of many scientific types of research undoubtedly confirm the negative influence of overtime work, work on holidays and Sundays on the stability of

\section{Free Sunday Background and Contemporary Legislation}

It can hardly be denied that Sunday as "the day of the Lord and as the day of rest" is a Christian institution (Tamarut, 1970). Sunday is celebrated in the church as the day of Christ's resurrection. Throughout the centuries, this fundamental reason for celebration is sociologically infused with Jewish fundamental social attitude that a man needs rest. Moreover, Jewish tradition has always emphasized that marriage and family. Due to work overload, less time remains for quality marital relationships and the establishment of intimacy among spouses. Considering that partners spend most of their time together during weekends (Lyonette, Clark,2009) spouses who have to work on weekends have even less time for each other than those who have normal working hours. The research made on the sample of married couples in Zagreb, Croatia (Čudina, Obradović,2006) shows that partner's absence from home reduces the feeling of intimacy with one another, which leads to loneliness and causes weakening of mutual support.

Besides, excessive stress associated with significant disruption of family dynamics and the relationship between husband and wife can ultimately lead to divorce. An enormous increase in the divorce rate has devastating consequences not only to all members of respective families but also to society as a whole.

Fifty years ago, the main reasons for divorce were mostly behavioral and fairly concrete such as alcoholism and neglect by a spouse (Chang,2003). However, in the last two decades reasons for divorce have become more effective and abstract natures as feeling unloved or incompatible in the areas of life values and interests. According to the results of some researches with an increased number of hours women spend at their workplaces, the probability of divorce increases (Lyonette, Clark,2009). Since the number of divorced marriages in a quarter of the counties in the Republic of Croatia on an annual basis exceeded the number of new marriages, it is no wonder that free Sunday is for the first time perceived and promoted in Croatia as one of the main measures of active demographic policy.

This paper is organized as follows. After the introduction, the second part of the paper is dedicated to the historical background and legislation in some European countries. The topic of the third part is the case study of Croatia consisting of statistical analysis of public opinion survey results. The public opinion survey on free Sunday has been carried out in October 2017 organized by Franciscan Institute for the Culture of Peace from Split. The final section contains concluding remarks. Consulted literature is listed at the end of the paper.

this vacation belongs to every man, not just to certain groups or individuals.

Therefore, the Israeli "Shabbat" as appreciating the Saturday as a holy day "appears already in the oldest parts of the Law (Exodus 20,8; 23,12; 34,21 )“( Spicq, Grilot, 1993 ), and is based on the cognition of the basic need of people and animals for rest. Saturday in Israel was originally a "social-ethical institution, i.e. exclusively day of the rest and 


\section{International Journal of Business and Applied Social Science (IJBASS)}

E-ISSN: 2469-6501

VOL: 6, ISSUE: 4

April/2020

DOI: 10.33642/fjbass.v6n4p2

\section{(C) Center for Promoting Education and Research (CPER) USA}

WWW.cpernet.org

(...) only after the Babylonian exile it becomes the day of special Divine Worship“(Tamarut, 1970).

After a long time, the Roman Empire launched the legalization of the free day, and instead of Sabbath, Sunday become the free day as the day of Christ's resurrection. Namely, by legitimate reforms of Emperor Constantine life's attitude has changed considerably. Milan edict that prescribed Constantine I and Licinius in 313 stopped the persecution of Christians. Other reforms followed and Sunday was also overturned on a non-working, public holiday by the law in 321. Works in the field are exempted from the rest "because it is not always a good time for them" (Tamarut, 1970). Thus, those works who were defined as "farming or hard-working" through the later centuries were exempted by this law for practical reasons.

Modernization, urbanization, secularization, and industrialization have brought up the question of free Sunday into the center again. "Machine" and "Profit" caused an increase in working hours, and working conditions became worse and worse. Based on the scientific analysis of that time, the benefit of the workers' vacations is recognized and the free Sunday is reinstated in the legal regulations. Thus, the implementation of free Sunday in the legislations of the western countries at the end of the 19th and the beginning of the 20th century was not motivated by spirituality and/or the workers' needs. It has already seen the benefit of the workers' rest "for human-social and economic reasons" (Tamarut, 1970).

It is certainly the tradition of thousands of years of practice that has influenced the determination of Sunday as a non-working day. Thus, the non-working Sunday was reintroduced to Switzerland 1877, in Germany 1891, in France 1906 and Italy in 1907. It should be noted that protestant countries such as England and the United States have not abolished free Sunday (Sabotič, 2005).

Due to the character of this paper, it is possible to provide only a concise description of the Sunday work models that are currently valid in certain European countries. In the EU, about $30 \%$ of employees regularly work on Sundays. In Austria, this percentage is $16 \%$, tending to grow, and in Germany $23 \%$. According to Eurostat data, Sunday is mostly workday in England and Denmark, while Spain and Italy recorded the lowest level of Sunday work. Work on Sunday (in retail trade) is prohibited in Belgium, Denmark, France, Greece, Italy, Norway, Germany, Luxembourg, and Austria.

However, there are exceptions in all of these countries: work in retail shops in Norway is allowed only three weeks before Christmas from 14:00 to 20:00; in Greece, there are no work restrictions in smaller places and tourist zones; in the Netherlands, it is allowed to work 12 Sundays per year; in Spain 8 Sundays per year; in Finland just from 12:00 to 21:00h.

In Germany, since 2006, working time has been allocated to federal states. So, work on Sunday in Bavaria is prohibited altogether but in most other federal states it is allowed to work only 4-6 Sundays per year. Berlin was allowed to work full-time 10 Sundays from $1 \mathrm{pm}$ to $8 \mathrm{pm}$. However, the Constitutional Court of Germany issued an act, in December 2009, according to which only exceptionally can shop be open on Sundays. This law emphasized that activities typical for workdays cannot be passed on to Sunday, and that "pure financial interests of the shop owners are not strong enough to open trade on Sunday".

Thanks to a strong civilian fight for free Sunday; in Austria, the Constitutional Court issued a decision in 2012 which prohibited work on Sundays. Shops can be open on working days from 6 to 21h, on Saturdays from 6 to $18 \mathrm{~h}$. They are closed on Saturdays after 18h, on Sundays, on holidays and feasts. Exceptions are the stations, airports, ports and public events.

Due to multiple and various negative effects of work on Sundays throughout modern Europe in recent years numerous initiatives, associations and mass movements for free Sunday have been established. Among them are European Sunday Alliance and European Citizens' Initiative for a work-free Sunday in Europe which advocates nonworking Sunday be implemented in European legislation and be valid throughout the EU.

\section{Case Study of Croatia}

As an integral part of the EU, Croatia shares its destiny and all that has been said previously refers to Croatia, too. Croatia is a member of all-important European initiatives for free Sunday and is particularly active in the two above mentioned. Croatian Sunday Alliance (CSA) has been established in 2017. It is an association of trade unions, academic, social and religious institutions as well as NGOs. It's already mentioned that CSA as a member of the European Sunday Alliance has significantly contributed to the promotion of free Sunday as a measure of active demographic policy.

Free Sunday is particularly opposed to the competition of the burly capital owners. For decades they have been misrepresenting realities of the work on Sundays, falsely claiming, for example, that it increases economic activities and employment rate in Croatia. However, no economic theory proves that and the available indicators disclaim it. Moreover, the data of the Croatian Ministry of Finance Tax Department Zagreb in Table 1 shows far the lowest fiscal turnover in retail trade on Sundays and holidays. 
Table 1 Average turnover in fiscalization in G47 Retail trade by day in 2015, 2016 and 2017 in Kuna

\begin{tabular}{|c|c|c|c|c|c|c|c|}
\hline \multicolumn{7}{|c|}{ Average turnover in fiscalization in G47 Retail trade by day in 2015, in Kuna } \\
\hline Monday & Tuesday & Wednesday & Thursday & Friday & Saturday & Sunday & Holidays \\
\hline 217.353 .239 & 215.138 .930 & 219.655 .595 & 232.188 .885 & 242.538 .963 & 256.457 .213 & 135.767 .295 & 105.583 .320 \\
\hline \multicolumn{7}{|c|}{ Average Annual turnover in 2015 } & 79.348 .724 .279 \\
\hline \multicolumn{7}{|c|}{ Average Fiscal Daily G47 in 2015 } & 241.393 .765 \\
\hline \multicolumn{7}{|c|}{ Average turnover in fiscalization in G47 Retail trade by day in 2016 in Kuna } \\
\hline Monday & Tuesday & Wednesday & Thursday & Friday & Saturday & Sunday & Holidays \\
\hline 221.929 .611 & 221.976 .522 & 220.493 .272 & 248.633 .722 & 259.816 .483 & 269.003 .246 & 141.836 .200 & 110.390 .856 \\
\hline \multicolumn{7}{|c|}{ Average Annual turnover in 2016 } & 82.589 .145 .368 \\
\hline \multicolumn{7}{|c|}{ Average Fiscal Daily G47 in 2016 } & 226.271 .631 \\
\hline \multicolumn{7}{|c|}{ Average turnover in fiscalization in G47 Retail trade by day in 2017 in Kuna } \\
\hline Monday & Tuesday & Wednesday & Thursday & Friday & Saturday & Sunday & Holidays \\
\hline 235.914 .507 & 234.048 .728 & 238.983 .062 & 256.322 .650 & 274.511 .389 & 288.579 .629 & 156.616 .216 & 118.345 .147 \\
\hline \multicolumn{7}{|c|}{ Average Annual turnover in 2017 } & 88.061 .240 .658 \\
\hline \multicolumn{7}{|c|}{ Average Fiscal Daily G47 in 2017 } & 241.263 .673 \\
\hline
\end{tabular}

Source: ISPU - Ministry of finance RH - Tax Department Zagreb, April, 2018.

The table shows that in all analyzed years the buyers population aged 18 and on were studied, a two-step stratified in retail stores most often buy on Saturday, followed by Friday, Thursday, Wednesday, Monday, Tuesday, rather rarely they go shopping on Sunday, and rarely on holidays. These buying habits are relatively stable in the entire analyzed period.

In 2015 and 2016 on Saturdays, the purchases were 89\% higher than on Sundays, and in 2017 the sales realized on Saturday exceeded the Sunday sales for $84 \%$ on average.

The difference is even higher when comparing turnover in retail trade on Saturday and holiday. The survey shows that in 2015 the average Saturday turnover was even $151 \%$ higher than average turnover on the days of holiday. In 2016 and 2017 the average retail turnover on Saturday exceeds the turnover realized on days of holiday for $144 \%$.

CSA significantly contributed to the promotion of the values of free Sunday. On behalf of it, the Franciscan Institute for the Culture of Peace from Split conducted a survey, in October 2017, to find out prevailing public attitudes to the value of non-working Sunday, which authors have used as the case study of Croatia.

The public opinion survey was carried out by a specialized agency Ipsos Public Affairs. It was conducted by telephone interviews. Since the views of the Croatian random sample was used with the following stages:

- By random selection of place of residence within the stratum - the stratums are defined by region (6) and size of the place of residence (4 categories).

- The household was chosen by the random selection of the phone number.

- The respondent was chosen by quota.

The final realized sample consists of 603 respondents.

As far as methodology is concerned, testing of hypothesis about the difference in the proportions of the two statistical populations has been applied. The usual level of significance of the 5\% test was used. Post-stratification of the two-step stratified random sample has been carried out based on gender, age, size of residence, regions and education level.

From the results of this comprehensive research, only some basic attitudes and answers to the relevant issues are presented in this paper. The first one is presented on Figure 1 with the answers to the question: "How often you, if ever, go to the next places on Sundays?"

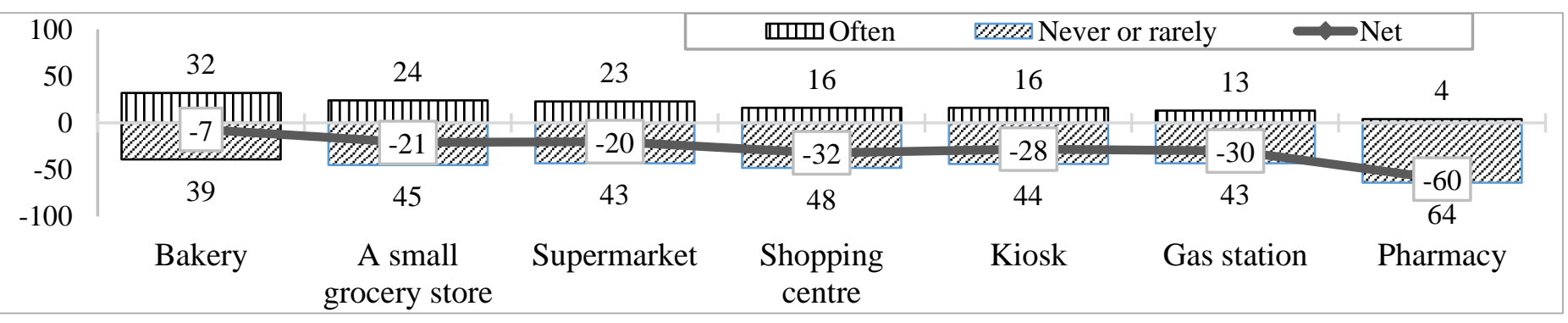




\title{
International Journal of Business and Applied Social Science (IJBASS)
}

\author{
E-ISSN: 2469-6501 \\ VOL: 6, ISSUE: 4 \\ April/2020 \\ DOI: 10.33642/fjbass.v6n4p2 \\ https://iibassnet.com/
}

\section{(C) Center for Promoting Education and Research (CPER) USA}

WWW.cpernet.org

The random stratified sample enabled authors to statistically analyze the answers to the aforementioned question for some demographic features. The frequency of going to the respective places has been statistically analyzed about the answer: "I rarely or never visit them on Sundays". The analysis has been carried out for all of the places visited on Sundays and the results are very similar for each of them. Therefore, below are presented more precise results of visiting the shopping centres on Sundays based on demographic categories.

Statistical analysis has shown that there is no statistically significant difference between the frequency of going to a shopping centre on Sundays between men and women. The answer "I rarely or never go shopping on Sundays" gave $48 \%$ of male and $50 \%$ of female respondents. The same answer has been given by $47 \%$ of the urban and $52 \%$ of the rural population. It shows that neither their responses statistically differ significantly.

Analysis of the profile of the respondents according to the level of education reveals that $45 \%$ of them who have elementary school education, 51\% middle and $46 \%$ high school or college education "rarely or never" go shopping on Sundays.

The respondents up to 30 years visit shopping centres on Sundays more often (41\% rarely or never) while those between 45 and 60 years old do it the rarest (59\% rarely or never). »Rarely or never « go shopping on Sundays $44 \%$ of the respondents between 30 and 44 years old and those over 60 do not differ much (45\%).

The analysis done according to the particular regions of Croatia shows that $56 \%$ of the population of Zagreb and its surroundings go shopping on Sundays »rarely or never «; in Slavonija 41\%; in Kordun and Lika 57\%; in North Croatia 43\%; in Primorje and Istra 46\% and Dalmatia 49\%.

Even more than two thirds $(67.5 \%)$ of respondents claim that not-working on Sundays within their regular business is important or exceptionally important for them. What they particularly think about work on Sundays can be seen distinctly from the Figure 2.

$\begin{array}{lll}\square \text { I completely agree } & \square \text { I mostly agree } & \text { \$ I mostly disagree } \\ \square \text { I do not agree at all } & \text { 程 do not know, I'm not sure } & \end{array}$

It is extremely important for the harmonious and good family relationships that the family is together on Sunday

Work on Sundays is bad because employeers are not paid well for this work beyond their normal working hours

Work on Sundays is bad because it makes it difficult to match the family with business commitments and the need for free time

Work on Sundays is a pure exploitation of employeers

Except emergency services, no one should work on Sundays

Work on Sundays is bad because because people are drawn to shopping centers instead of spending their time at a higher quality

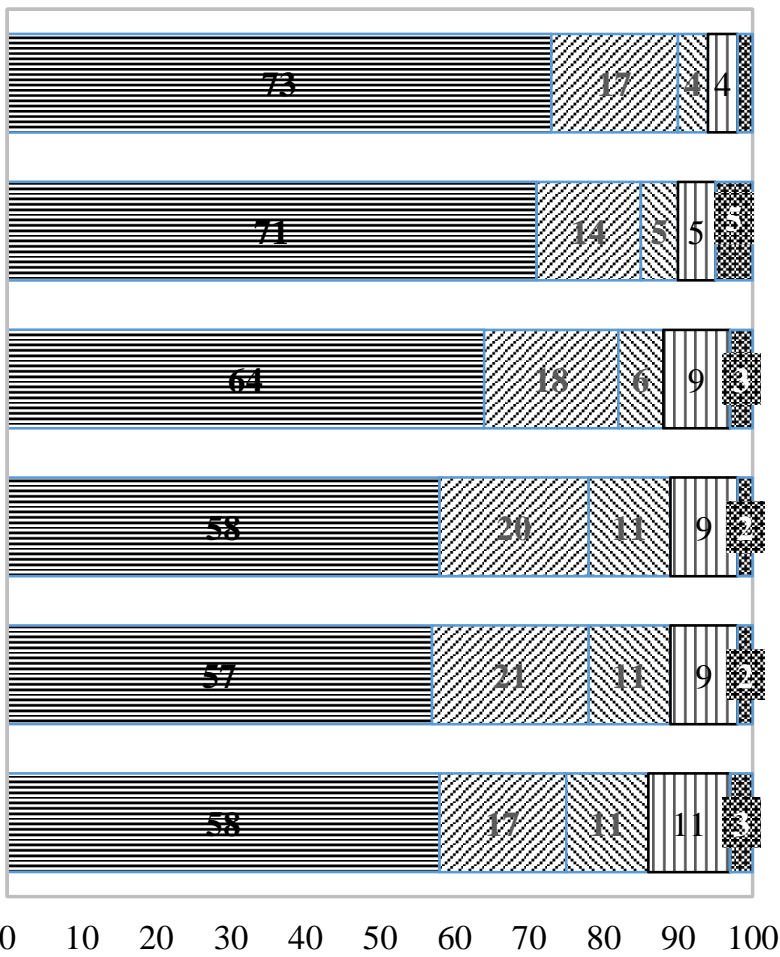

Fig. 2. Attitudes about work on Sundays

Source: Authors according Ipsos Public Affairs 2017

The share of different attitudes of respondents, resulting in the case of simulation of the Sunday work ban has been statistically analyzed according to their basic d-mnoraphic features. Although the analysis has covered the answers to all the questions dealing with Sunday shopping in bakery, small grocery store, supermarket, shopping centre, kiosk, gas station and pharmacy in Table 2 are highlighted only the results referring to the places where it would be the 
easiest (shopping centre) or the most difficult (pharmacy) for respondents to adjust to work-free Sunday.

Table 2 presents attitudes on adjustment to the change in the situation of the Sunday work ban. On average $61 \%$ of respondents in the entire sample have answered ,it wouldn't be a problem ", to adjust to the situation where shopping centre does not work on Sundays, whereby there's no statistically significant difference in their answers considering gender criteria. Namely, $60 \%$ of male respondents would get used to work-free Sunday in shopping centres without problems, while the women show a somewhat higher percentage $-62 \%$.

Table 2. Attitudes on adjustment to the change in situation of Sunday work ban

\begin{tabular}{|c|c|c|c|c|c|}
\hline \multicolumn{6}{|c|}{ Percentage of change adaption responses by demographic criteria } \\
\hline \multirow{3}{*}{\multicolumn{2}{|c|}{ SAMPLE }} & \multicolumn{2}{|c|}{ "Would not be a problem" } & \multicolumn{2}{|c|}{ "Hard + very hard" } \\
\hline & & Shopping center & Farmacy & $\begin{array}{l}\text { Shopping } \\
\text { center }\end{array}$ & Farmacy \\
\hline & & $61 \%$ & $36 \%$ & $6 \%$ & $17 \%$ \\
\hline \multirow{2}{*}{ Gender } & Male & $60 \%$ & $36 \%$ & $6 \%$ & $16 \%$ \\
\hline & Female & $62 \%$ & $36 \%$ & $6 \%$ & $17 \%$ \\
\hline \multirow{4}{*}{ Age } & to 30 years & $58 \%$ & $29 \%$ & $13 \%$ & $25 \%$ \\
\hline & from 30 to 44 years & $68 \%$ & $34 \%$ & $3 \%$ & $22 \%$ \\
\hline & from 45 to 60 years & $74 \%$ & $41 \%$ & $3 \%$ & $13 \%$ \\
\hline & more than 60 years & $44 \%$ & $37 \%$ & $8 \%$ & $11 \%$ \\
\hline \multirow{3}{*}{ Education } & Primary school & $48 \%$ & $43 \%$ & $7 \%$ & $7 \%$ \\
\hline & High school & $64 \%$ & $33 \%$ & $6 \%$ & $20 \%$ \\
\hline & Elementary school & $68 \%$ & $36 \%$ & $6 \%$ & $19 \%$ \\
\hline \multirow{2}{*}{$\begin{array}{l}\text { Category of } \\
\text { community }\end{array}$} & City & $62 \%$ & $34 \%$ & $6 \%$ & $18 \%$ \\
\hline & Village & $59 \%$ & $40 \%$ & $6 \%$ & $14 \%$ \\
\hline \multirow{6}{*}{ Region } & $\begin{array}{c}\text { Zagreb and surrounding } \\
\text { area }\end{array}$ & $70 \%$ & $40 \%$ & $6 \%$ & $13 \%$ \\
\hline & Northern Croatia & $57 \%$ & $40 \%$ & $7 \%$ & $16 \%$ \\
\hline & Slavonia & $46 \%$ & $25 \%$ & $9 \%$ & $19 \%$ \\
\hline & Banovina, Kordun, Lika & $57 \%$ & $42 \%$ & $10 \%$ & $26 \%$ \\
\hline & Croatian coast and Istria & $69 \%$ & $42 \%$ & $5 \%$ & $15 \%$ \\
\hline & Dalmatia & $63 \%$ & $31 \%$ & $3 \%$ & $17 \%$ \\
\hline \multirow{5}{*}{ Job status } & Employee & $66 \%$ & $34 \%$ & $6 \%$ & $21 \%$ \\
\hline & Pensioners & $55 \%$ & $39 \%$ & $7 \%$ & $13 \%$ \\
\hline & Students & $51 \%$ & $25 \%$ & $12 \%$ & $16 \%$ \\
\hline & Unemployed & $65 \%$ & $36 \%$ & $2 \%$ & $11 \%$ \\
\hline & Other & $54 \%$ & $61 \%$ & & $9 \%$ \\
\hline \multirow{4}{*}{$\begin{array}{c}\text { Personally, } \\
\text { works on } \\
\text { Sundays }\end{array}$} & Yes, currently & $70 \%$ & $27 \%$ & $7 \%$ & $25 \%$ \\
\hline & No, but worked before & $66 \%$ & $40 \%$ & $2 \%$ & $17 \%$ \\
\hline & No, never & $65 \%$ & $35 \%$ & $8 \%$ & $21 \%$ \\
\hline & Labor inactive & $56 \%$ & $39 \%$ & $6 \%$ & $12 \%$ \\
\hline
\end{tabular}

Source: Authors according Ipsos Public Affairs 2017

However, the analysis based on the age criteria shows statistically significant differences in adjustment to workfree Sunday in the shopping centre. The adjustment to such a situation would be most difficult for the oldest ones, and the easiest for the respondents aged 45 to 60 . Namely even $74 \%$ of this last group have answered that the adjustment would not be a problem, on the contrary, only $44 \%$ of respondents above 60 years of age have given the same answer.

Considering the type of residence, there's no statistically significant difference in adjustment to work-free Sunday between rural $(59 \%)$ and urban $(62 \%)$ population. Differing from this demographic feature, upon the analysis based on the respondents' level of education, the resulting answers have shown statistically significant differences. While only $48 \%$ of the respondents with elementary school education would not find it problematic to get used to workfree Sunday in the shopping centre, even $68 \%$ of respondents with the highest level of education have given such an answer.

Differences in answers are also statistically significant according to the respondents' region of residence. Namely, the respondents from Slavonia have answered only in $46 \%$ cases that they would adjust without problems to work-free Sunday in the shopping centre, the same answer has been obtained even by $70 \%$ of respondents from the territory of Zagreb and its surroundings.

The answers analyzed according to the work status of respondents also show statistically significant $\mathrm{di}^{f} f$ Students would have no problems getting used to a

Sunday of the shopping centre $(51 \%)$, even $66 \%$ of the employed respondents would do the same. 
Among the respondents who work on Sundays, 70\% of those with permanent work contracts would adjust without problem to work-free Sundays of the shopping centre, while only $56 \%$ of those who are sometimes engaged on a parttime basis for Sunday work give the same answer.

The resulting share of different attitudes of respondents in the case of simulation of Sunday work ban in pharmacy has also been subject to statistical analysis according to their basic demographic indicators. Percentages of the answer ,it wouldn't be a problem“to adjust to Sunday work-ban in pharmacy are presented in the third column of Table 2.

The answers about the adjustment to work-free Sunday of the shopping centre ,hard and very hard"are illustrated in the fourth column of Table 2 and reveal the same logic as the data presented in the first row of the same Table. This answer has been given by $6 \%$ of all respondents, equal percentage by men and by women. There are no statistically significant differences in the answers when analyse according to gender, education level and type of respondents' residence.
Namely, the percentage of respondents who would find it ,hard and very hard"to adjust to a work-free Sunday of shopping centre according to all stated demographic categories remain at the level of population average of $6 \%$.

The respondents' answers analyzed according to work status show statistically significant differences. The students have answered even in $12 \%$ of the cases that they would find it "hard and very hard" to adjust to a work-free Sunday of the shopping centre, and unemployed persons have given such an answer only in $2 \%$ of the cases.

The fifth and sixth columns of Table 2 present demographic features of the percentage of respondents who would find it ,hard and very hard" to adjust to a work-free Sunday of pharmacy.

In order to simulate the effects of work-free Sunday as the measure of demographic policy, the respondents have been asked as follows: "Would you mind if your family member had to work on Sundays?" The answers are illustrated in Figure 3.

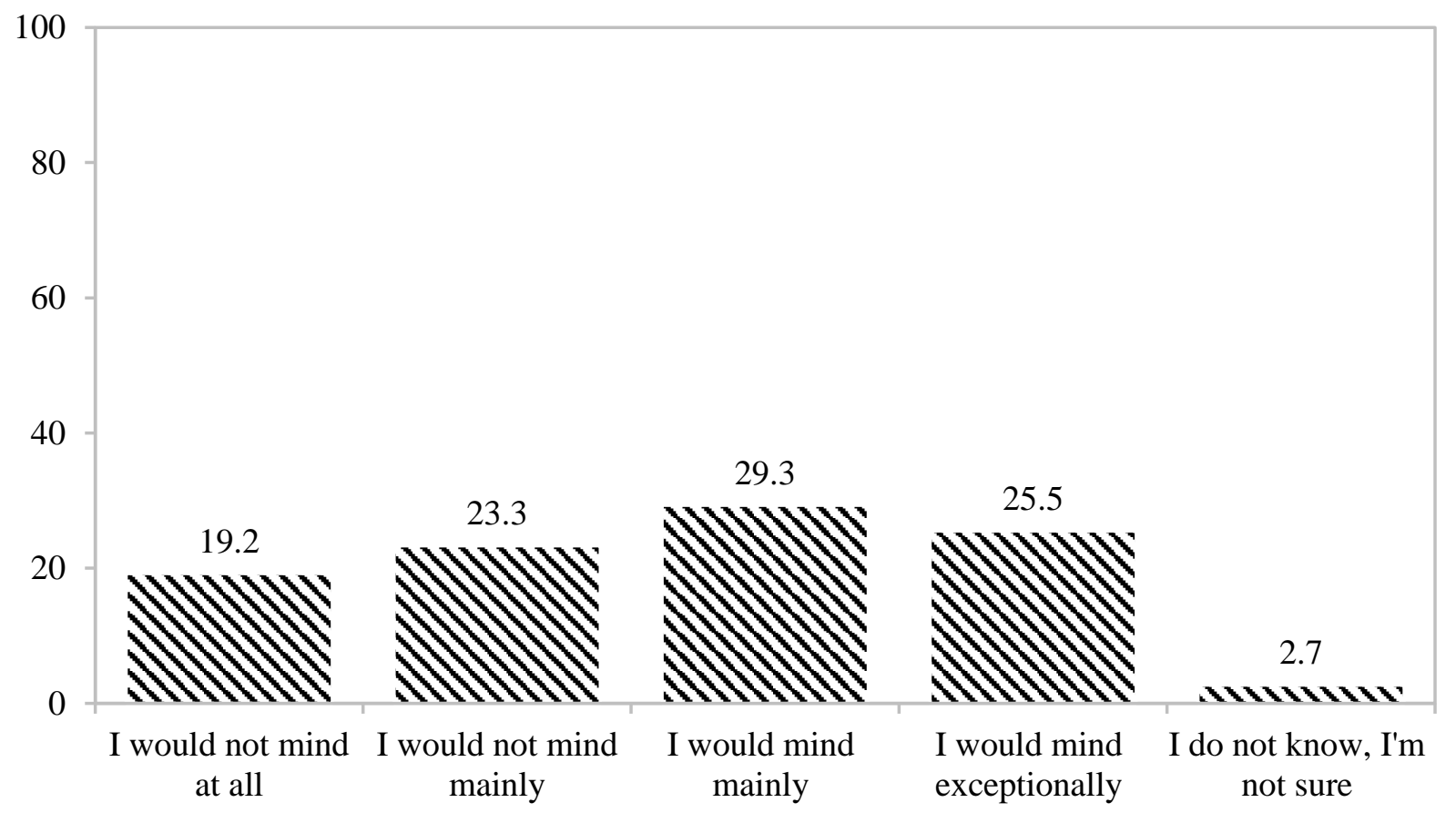

Fig. 3. Attitudes on situation that family member had to work on Sundays Source: Authors according Ipsos Public Affairs 2017

The answers of the respondents to the question: „Would you mind if your family member had to work on Sundays?" have been statistically analyzed according to demographic features in Table 3.

The answer ,I would not mind if my family member had tn work on Sundays" has been given by $42 \%$ of precisely $46 \%$ men and $39 \%$ women.
According to the type of residence, the share of answers to this question doesn't show a statistically significant difference, since the answers of both, rural and urban population correspond to the average of the interviewed population.

The highest share of this answer is recorded in the youngest age group of respondents - 58\% in the group aged below 30 years. Meanwhile, this answer reaches only $32 \%$ in the age group 45 to 60 . 
The answers of respondents with different levels of education also show statistically significant differences. $37 \%$ of those with elementary school education would not mind if their family member had to work on Sundays, and those with the highest level of education would not mind it in $56 \%$ of cases.

Regional differences noted in this answer are minor. Thus, the respondents from the area of Banovina, Lika, and Kordun record the lowest percentage of such answers (35\%), differing from Dalmatia with the highest percentage $(45 \%)$ of the above answer.
The survey shows statistically significant differences in the answers analyze according to work status. Thus $36 \%$ of pensioners would not mind if their family member had to work on Sundays, this answer among unemployed respondents has reached the level of even $60 \%$.

Considering that the answer „I do not know" to this question (together with those who have not answered at all) has been given on average by $2,7 \%$ respondents, the relations of statistically significant differences according to demographic features remain unchanged and are illustrated in the last row of Table 3.

Table 3. Attitudes on situation that family member had to work on Sundays

\begin{tabular}{|c|c|c|c|c|c|}
\hline \multicolumn{6}{|c|}{ Answers about situation that family member had to work on Sunday } \\
\hline & & $N$ & $\begin{array}{c}\text { Would not } \\
\text { mind }\end{array}$ & $\begin{array}{l}\text { Would } \\
\text { mind }\end{array}$ & $\begin{array}{l}\text { Do not know- } \\
\text { Now reply }\end{array}$ \\
\hline \multicolumn{2}{|c|}{ Sample } & 603 & $42 \%$ & $55 \%$ & $3 \%$ \\
\hline \multirow{2}{*}{ Gender } & Male & 288 & $46 \%$ & $50 \%$ & $4 \%$ \\
\hline & Female & 315 & $39 \%$ & $59 \%$ & $2 \%$ \\
\hline \multirow{4}{*}{ Age } & to 30 years & 115 & $58 \%$ & $42 \%$ & \\
\hline & From 30 to 44 years & 120 & $45 \%$ & $53 \%$ & $2 \%$ \\
\hline & From 45 to 60 years & 197 & $32 \%$ & $63 \%$ & $5 \%$ \\
\hline & More than 60 years & 172 & $42 \%$ & $55 \%$ & $3 \%$ \\
\hline \multirow{3}{*}{ Education } & Primary school & 144 & $37 \%$ & $56 \%$ & $6 \%$ \\
\hline & High school & 345 & $40 \%$ & $58 \%$ & $2 \%$ \\
\hline & Elementary school & 114 & $56 \%$ & $43 \%$ & $1 \%$ \\
\hline \multirow{2}{*}{$\begin{array}{l}\text { Category of } \\
\text { community }\end{array}$} & City & 371 & $42 \%$ & $56 \%$ & $2 \%$ \\
\hline & Village & 232 & $43 \%$ & $53 \%$ & $4 \%$ \\
\hline \multirow{6}{*}{ Region } & $\begin{array}{c}\text { Zagreb and } \\
\text { surrounding area }\end{array}$ & 157 & $44 \%$ & $56 \%$ & $0 \%$ \\
\hline & Northern Croatia & 103 & $43 \%$ & $51 \%$ & $6 \%$ \\
\hline & Slavonia & 100 & $44 \%$ & $59 \%$ & $2 \%$ \\
\hline & $\begin{array}{c}\text { Banovina, Kordun, } \\
\text { Lika }\end{array}$ & 52 & $43 \%$ & $51 \%$ & $14 \%$ \\
\hline & $\begin{array}{l}\text { Croatian coast and } \\
\text { Istria }\end{array}$ & 75 & $39 \%$ & $55 \%$ & $1 \%$ \\
\hline & Dalmatia & 117 & $35 \%$ & $55 \%$ & \\
\hline \multirow{5}{*}{ Job status } & Employees & 303 & $45 \%$ & $53 \%$ & $2 \%$ \\
\hline & Pensioners & 203 & $36 \%$ & $60 \%$ & $4 \%$ \\
\hline & Students & 36 & $41 \%$ & $59 \%$ & \\
\hline & Unemployed & 42 & $60 \%$ & $32 \%$ & $8 \%$ \\
\hline & Other & 20 & $39 \%$ & $61 \%$ & \\
\hline \multirow{4}{*}{$\begin{array}{c}\text { Personally } \\
\text { works on } \\
\text { Sundays }\end{array}$} & Yes, currently & 114 & $50 \%$ & $48 \%$ & $2 \%$ \\
\hline & $\begin{array}{c}\text { No, but worked } \\
\text { before }\end{array}$ & 61 & $38 \%$ & $61 \%$ & $1 \%$ \\
\hline & No, never & 116 & $40 \%$ & $57 \%$ & $3 \%$ \\
\hline & Labor inactive & 313 & $42 \%$ & $55 \%$ & $4 \%$ \\
\hline
\end{tabular}

Source: Authors according Ipsos Public Affairs 2017

Table 4 provides the review of the answers to the Sundays. These answers show statistically significant question „How important is it to you personally not to work on Sundays?" expressed in percentage and analyze according to demographic features.

For more than two-thirds of respondents $(68 \%)$, it is differences between male and female respondents. Even $76 \%$ of women give such answer and only $58 \%$ of the population. important that they personally don't have to work on 
Table 4. Answers to the question: "How important is it to you personally not to work on Sundays?"

\begin{tabular}{|c|c|c|c|c|c|}
\hline \multicolumn{6}{|c|}{$\begin{array}{c}\text { Percentage of answers to the question "How important is it to you personally not to work on } \\
\text { Sundays?" }\end{array}$} \\
\hline & & $N$ & It is important & $\begin{array}{c}\text { It is not } \\
\text { important }\end{array}$ & $\begin{array}{l}\text { Do not know- } \\
\text { Now reply }\end{array}$ \\
\hline \multicolumn{2}{|c|}{ Sample } & 603 & $26 \%$ & $68 \%$ & $7 \%$ \\
\hline \multirow{2}{*}{ Gender } & Male & 288 & $34 \%$ & $58 \%$ & $7 \%$ \\
\hline & Female & 315 & $18 \%$ & $76 \%$ & $6 \%$ \\
\hline \multirow{4}{*}{ Age } & to 30 years & 115 & $36 \%$ & $61 \%$ & $3 \%$ \\
\hline & from 30 to 44 years & 120 & $24 \%$ & $73 \%$ & $2 \%$ \\
\hline & from 45 to 60 years & 197 & $21 \%$ & $72 \%$ & $6 \%$ \\
\hline & more than 60 years & 172 & $24 \%$ & $62 \%$ & $13 \%$ \\
\hline \multirow{3}{*}{ Education } & Primary school & 144 & $22 \%$ & $62 \%$ & $17 \%$ \\
\hline & High school & 345 & $24 \%$ & $72 \%$ & $4 \%$ \\
\hline & Elementary school & 114 & $34 \%$ & $63 \%$ & $3 \%$ \\
\hline \multirow{2}{*}{$\begin{array}{l}\text { Category of } \\
\text { community }\end{array}$} & City & 371 & $25 \%$ & $71 \%$ & $5 \%$ \\
\hline & Village & 232 & $27 \%$ & $63 \%$ & $10 \%$ \\
\hline \multirow{6}{*}{ Region } & $\begin{array}{c}\text { Zagreb and } \\
\text { surrounding area }\end{array}$ & 157 & $25 \%$ & $68 \%$ & $7 \%$ \\
\hline & Northern Croatia & 103 & $29 \%$ & $62 \%$ & $9 \%$ \\
\hline & Slavonia & 100 & $22 \%$ & $72 \%$ & $6 \%$ \\
\hline & $\begin{array}{c}\text { Banovina, Kordun, } \\
\text { Lika }\end{array}$ & 52 & $33 \%$ & $65 \%$ & $2 \%$ \\
\hline & $\begin{array}{l}\text { Croatian coast and } \\
\text { Istria }\end{array}$ & 75 & $23 \%$ & $62 \%$ & $15 \%$ \\
\hline & Dalmatia & 117 & $25 \%$ & $73 \%$ & $2 \%$ \\
\hline \multirow{5}{*}{ Job status } & Employees & 303 & $22 \%$ & $74 \%$ & $4 \%$ \\
\hline & Pensioners & 203 & $25 \%$ & $63 \%$ & $12 \%$ \\
\hline & Students & 36 & $54 \%$ & $46 \%$ & \\
\hline & Unemployed & 42 & $30 \%$ & $59 \%$ & $11 \%$ \\
\hline & Other & 20 & $16 \%$ & $75 \%$ & $10 \%$ \\
\hline
\end{tabular}

Source: Authors according Ipsos Public Affairs 2017

$61 \%$ of respondents aged below 30 years have declare that it is important for them not to work on Sundays, answered that it is important to them that they personally do not have to work on Sundays, and this percentage has increased to $73 \%$ in the group aged 30 to 40 years.

The rural population considers it important not to and the same applies to $73 \%$ of the Dalmatian population. According to work status, the employed respondents show the highest rate of those for whom it is important that they work on Sundays in $63 \%$ of cases, and urban respondents even in $71 \%$.

Regional differences are similar. Namely $62 \%$ of the personally do not have to work on Sundays (74\%), among them only $46 \%$ of students.

Modalities and frequency of the answer to the population of North Croatia and Croatian Littoral \& Istria question „How important are it to you personally not to work on Sundays?" are illustrated in Figure 4. 
I do not know, I'm not sure

It is exceptionally important for me I do not know, I'm not sure

It is important for me to some extent

It does not matter to me to some extent

It does not matter to me at all
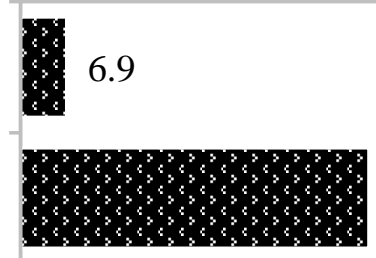

52.1

15.4

10.9

\section{6}

$\begin{array}{lllll}20 & 40 & 60 & 80 & 100\end{array}$

Fig. 4. Answers on the question "How important is it to you personally that you do not work on Sundays? Source: Authors according Ipsos Public Affairs 2017

Figure 5 shows answers about personal support to maximum limitation of work on Sunday

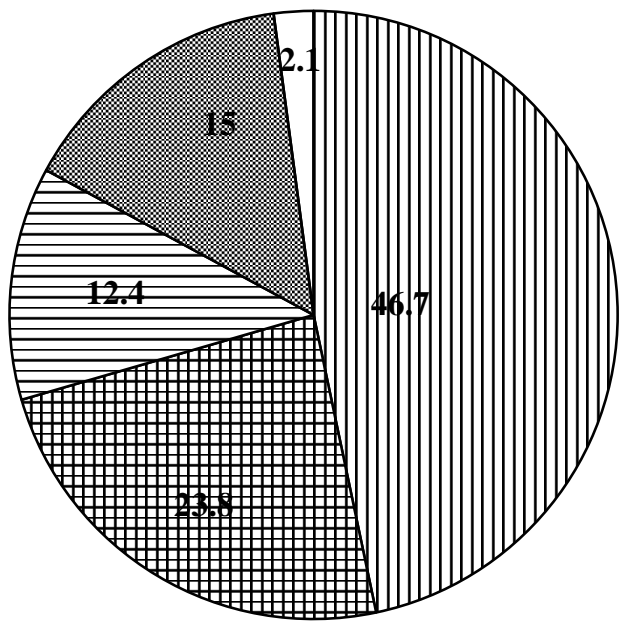

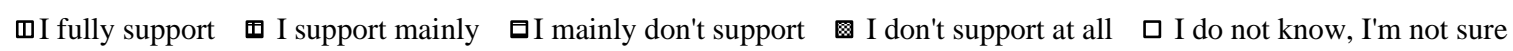

Fig. 5. Support to limitation of work on Sundays? Source: Authors according Ipsos Public Affairs 2017

It is highly indicative for integral conclusions of this research that even $70 \%$ of all the respondents support the limitation of work on Sundays. After the accomplished methodology of stratification, the results of statistical analysis of the frequency of respondents' answers according to their demographic features are illustrated in Table 5.

It is interesting to set aside according to demographic features those groups of respondents who have more often supported the limitation of work on Sundays, differing from the respondents who show the average result on the level of the sample as a whole. These are women who support the limitation of Sunday work in $73 \%$ of cases. Age criteria show the major share of supporters of Sunday work limitation in groups aged 30 to $45(74 \%)$, and 45 to $60(77 \%)$. The respondents with secondary school education also support Sunday work limitation above average (73\%), just like the urban population $(71 \%)$. Regions, where the respondents prefer Sunday work limitation above average, are North Croatia (73\%), Slavonia (75\%) and Croatian Littoral \& Istria $(76 \%)$. Analysis of the respondents according to work status criteria shows that work-free Sunday is mostly (75\%) urged by the employed persons. 


\section{International Journal of Business and Applied Social Science (IJBASS)}

E-ISSN: 2469-6501

VOL: 6, ISSUE: 4

April/2020

DOI: $10.33642 /$ jjbass.v6n4p2

CPER

https://iibassnet.com/

\section{(C) Center for Promoting Education and Research (CPER) USA}

WWW.cpernet.org

\section{Conclusion}

This paper tries to provide the answer to the crucial question of whether work-free Sunday can be considered only as of the economic issue or concerns deeply almost all the segments of life in general. Moreover, the authors through the results of the public opinion research want to show and promote work-free Sunday as one of the major socio-economic phenomena, which in the modern world becomes a political and ideological issue as a fundamental human right which, inter alia, is the true notion of human freedom and welfare. Besides, as a member of the European Sunday Alliance, Croatia is the first EU member state which promotes free Sunday as one of the measures of active demographic policy.

The case study is based on the results of the research of public opinion about the work-free Sunday, undertaken in October 2017. Along with results of classical statistical methods applied in the processing of public opinion research, the methodology of this research has also involved hypothesis testing about the difference in the proportion of the two statistical populations as well as post-stratification of the two-step stratified random sample on the basis of gender, age, size of residence, regions and education level.

In recent months, after a long silence, free Sunday has recurrently appeared as the topic of discussion in Croatia. Namely, for decades the burly capital owners have been misrepresenting realities of the work on Sundays, falsely claiming, for example, that it increases economic activities and employment rate in Croatia. However, no economic theory proves that and the available indicators disclaim it.

Moreover, the data of the Croatian Ministry of Finance-Tax Department Zagreb show far the lowest fiscal turnover in retail trade on Sundays and holidays. In all analyzed years, the buyers in retail trade most often buy on Saturday, followed by Friday, Thursday, Wednesday, Monday, Tuesday, rather rarely on Sunday, and almost never on holidays. These features remain relatively stable in the entire analyzed period.

In compliance with the character of this paper, the most important results of the comprehensive statistical analysis of this research have been highlighted. Almost onethird of the respondents visit the bakery at least every second Sunday, and almost one-fourth of them go to small grocery stores and supermarkets. The pensioners show the lowest Sunday shopping rate, on the contrary, young respondents, in particular students, practice Sunday shopping more often.

Almost all the respondents agree that it is important for the family to be together on Sundays, and think that Sunday work is bad and incurs numerous and long-lasting adverse consequences in all the segments of life. The respondents generally, in all subsets, distributed according to demographic features, to a high extent agree with those allegations which are directed against Sunday work, and they do not agree with those which justify it.

If raising the issue of free Sunday as a dominant political question, the answers of the respondents might be used as a general conclusion based on the results of public opinion research. The share of $47 \%$,fully supports the maximum limitation of Sunday work". If we add to the above percentage $24 \%$ of those who ,mostly support it", the final result reveals the truth, so different from the conclusions often imposed by media, that even $70 \%$ of respondents support the limitation of Sunday work. In $27 \%$ of the cases, the respondents do not support the limitation of Sunday work, and 2,7\% of them have not declared their attitude.

This work is only a part of the on-going research dealing with the free Sunday phenomenon and the authors have presented the beginnings of extensive public opinion statistical analysis. Therefore, the results of further researches by the same authors, that promote the values of the nonworking Sunday as the basis of well-being, can be expected soon.

\section{REFERENCES}

Bakshi, G., Panayotov, G., Skoulakis, G., (2011), "Improving the predictability of real economic activity and asset returns with forward variances inferred from option portfolios”, Journal of Financial Economics, No.100, pp. 475-495.

Batinić, L. (2014), „Socijalno značenje nedjelje, važnost obitelji i obiteljska dobrobit“, In Baloban, S., Črpić, G., "Kultura nedjelje i dostojanstvo radnika“, Zagreb: Centar za promicanje socijalnog nauka crkve, Kršćanska sadašnjost, Zagreb, pp. 37-46.

Brstilo, I. (2014), "Rad nedjeljom: put u potrošačko društvo“, In Črpić, G, Džolan, M. Slobodna nedjelja: kultura u nestajanju? Centar za promicanje socijalnog nauka crkve, Kršćanska sadašnjost, Franjevački institut za Kulturu mira, Hrvatsko katoličko sveučilište, Zagreb, pp.79.

Chang, J. (2003), "Self-Reported Reasons for Divorce and Correlates of Psychological Well-Being Among Divorced Korean Immigrant Women”, Journal of Divorce \& Remarriage, Vol. 40 No.1-2. Pp. 111-128.

Croatian Bureau of Statistics (2017), "Gross Domestic Product for Republic of Croatia", available at: https://www.dzs.hr/, (28. March 2019). 
Črpić, G, Džolan, M. (2014), "Slobodna nedjelja: kultura u nestajanju?", Centar za promicanje socijalnog nauka crkve, Kršćanska sadašnjost, Franjevački institut za Kulturu mira, Hrvatsko katoličko sveučilište, Zagreb. knjiga.

Čudina-Obradović, M. Obradović, J. (2006), "Psihologija braka I obitelji”, Zagreb, Golden -marketing, Tehnička

Čudina-Obradović, M. Obradović, J. (2002), "Raspored rada bračnog partnera i doživljaj bračne kvalitete drugog partnera : provjera efekta prijenosa" // Hrvatska revija za rehabilitacijska istraživanja, Vol. 38 No.1, pp. 25-39.

Davenport, T.H. (2005), "Thinking for a Living: How to Get Better Performance and Results from Knowledge Workers", Boston, Harvard Business School Press.

Del, C., Ximena, V., Ozden, C., Testaverde, M., Wagner, M. (2016), „Global migration of talent and tax incentives“, Evidence from Malaysia's returning expert program. Washington, D.C: World Bank Group-Development Research GroupTrade and International Integration Team.

Dorotić, J. (2014), „Pitanje rada nedjeljom u Europskoj uniji“, In Črpić, G, Džolan, M. Slobodna nedjelja: kultura u nestajanju?, Zagreb, Centar za promicanje socijalnog nauka crkve, Kršćanska sadašnjost, Franjevački institut za Kulturu mira, Hrvatsko katoličko sveučilište, pp.111.

Dorotić, J. (2014), „Kvaliteta života i neradna nedjelja“, In Črpić, G, Džolan, M. Slobodna nedjelja: kultura u nestajanju? Zagreb, Centar za promicanje socijalnog nauka crkve, Kršćanska sadašnjost, Franjevački institut za Kulturu mira, Hrvatsko katoličko sveučilište, pp. 39-40.

European Foundation for the Improvement of Living and Working Conditions - Eurofound (2016), Sixth European Working Conditions Survey - Overview report, Publications Office of the European Union, Luxembourg.

European Foundation for the Improvement of Living and Working Conditions - Eurofound (2016), Eurofound yearbook 2015, Living and working in Europe, Publications Office of the European Union, Luxembourg.

European Commission (2014), Working conditions, Directorate-General Employment, Social Affairs and Inclusion, Flash Eurobarometer 398 - TNS Political \& Social.

Franjevački institut za kulturu mira (2017), Stavovi i iskustva građana vezana uz rad nedjeljom. Socijalna istraživanja i korporativna reputacija: Ipsos Public Affairs, available at: http://franjevacki-institut.hr/sadrzaj/pdf/2017-1123-08-34-1312-.pdf, (22. March 2019).

Split.

Jurun, E., Ratković, N. (2017), "Poslovna statistika s primjerima u Microsoft Excelu", Ekonomski fakultet Split,

Jurun, E., Ratković, N., Ujević, I. (2017), "A cluster analysis of Croatian counties as the base for an active demographic policy", Croatian Operational Research Review, Vol. 8 No.1, pp. 221-236.

Lyonette, C., Clark, M. (2009), "Unsocial Hours: Unsocial Families? Working Time and Family Wellbeing”, Cambridge: Relationships Foundation, No.1106460.

Mravunac, D. (2014), „Razvoj odnosa prema nedjelji“, In Črpić, G, Džolan, M. Slobodna nedjelja: kultura u nestajanju? Zagreb, Centar za promicanje socijalnog nauka crkve, Kršćanska sadašnjost, Franjevački institut za Kulturu mira, Hrvatsko katoličko sveučilište, No. 1, pp. 39-40.

OECD (2019), “Tax Policy Reforms 2019”, OECD and Selected Partner Economies. Paris.

Pezo, S. (2019), “Topli obrok, naknada za smještaj i ostali (ne)oporezivi primitci radnika. RRIF, No. 22, pp.11-16.

Ravnić, A. (2004), “Osnove radnog prava-domaćeg, usporednog i međunarodnog. Zagreb, Pravni fakultet.

Sabotić, I. (2005), O dokolici, slobodnom vremenu i nedjelji u Europi i Hrvatskoj na prijelazu iz XIX. u XX stoljeće. In Baloban, S, Črpić, G. (2014). Kultura nedjelje i dostojanstvo radnika, Zagreb, Centar za promicanje socijalnog nauka crkve, Krščanska sadašnjost.

Tamarut, A. (1970), Dan Gospodnji i počinak od rada kroz povijest do danas. Bogoslovska smotra, Zagreb: Kršćanska sadašnjost, Vol. 40 No.1, pp. 29-37.

United Nations-Department of Economic and Social Affairs-Population Division (2019) 


\section{International Journal of Business and Applied Social Science (IJBASS)}

E-ISSN: 2469-6501

VOL: 6 , ISSUE: 4

April/2020

DOI: 10.33642/fjbass.v6n4p2

CPER https://iibassnet.com/

(C) Center for Promoting Education and Research (CPER) USA

WWW.cpernet.org

Vuleta, B., Jurun, E., Ratković, N. (2019), "Statistical analysis of the public opinion survey on free Sunday", Proceedings of the 15th International Symposium on Operational Research, Zadnik Stirn, L. Bled, Slovenian Society Informatika, ISBN 978-961-6165-55-6, pp. 326-331.

World Economic Forum (2019), “The Global Competitiveness Report 2019”, Geneva.

Zakon o trgovini. (2008/9), Narodne novine 87/08,96/08,116/08,76/09-OUSRH br. 642/2009. 